\title{
ANIMAL TROUBLES: GOETHE AND THE REYNARD THE FOX TRADITION
}

\author{
By Bent Gebert \\ St Hugh's College, Oxford
}

Goethe's 'Reineke Fuchs' is commonly regarded as a work of classical serenity, and although this view accords with Goethe's later reflections on 'Reineke Fuchs', it fails to recognize the concrete textual differences that set Goethe's epic apart from his models and which were conceived as a provocation. This essay outlines how Goethe's numerous changes transform Gottsched's 'Reineke der Fuchs' into a subversive response not only to the tradition of Reynard the Fox, but also to debates about the significance of rhetoric and the function of figurative language in eighteenth-century German literature.

[...] denn beide Parteien

Find ich verworren, wer mag die Reden alle verstehen! (Goethe, Reineke Fuchs, XI, 359-60)

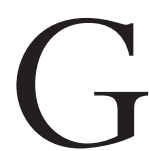

oethe's epic poem Reineke Fuchs is one of the most iridescent contributions to the narrative tradition of the vulpine trickster who violates the King's Peace in order to pursue his carnal desires and whom neither litigation nor feuding can restrain. Goethe drew on Johann Christoph Gottsched's 1752 edition and translation of the Low Middle German Reynke de Vos (Lübeck, I 498), a short fragment of the Dutch Reinaert (Delft, I485) and an eighteenth-century 'Volksbuch' version, and he was well aware that these texts formed only part of a rich and heterogeneous tradition. ${ }^{1}$ Gottsched's preface did not inform him about the earliest samples of the Reynard the Fox tradition. However, it did refer Goethe to the Old French Roman de Renart (between II65 and c.I250) and emphasized the popularity of the theme in Middle High German literature. Goethe followed his sources closely, in particular Gottsched's version, but nevertheless presented the work as his own, publishing Reineke Fuchs among other original writings such as Der GroßCophta in the second volume of his Neue Schriften (I794). This tension between adaptation and translation makes the work central to the issue of originality that is so fundamental to Goethe's self-perception and reputation. Whereas medieval authors and enlightened philologists like Gottsched stressed that the process of transmission constituted a joint venture of various writers working on and building a shared narrative project, Goethe blurred the indebtedness of his epic to the earlier

\footnotetext{
${ }^{1}$ For Goethe's sources see Käthe Scheel, 'Goethes Reineke Fuchs und seine Quellen', Mitteilungen aus dem Quickborn, XL (I949), 43-45; Hartmut Schmidt, "Pfingsten, das liebliche Fest": Das Volksbuch vom Reineke Fuchs, Jugendlektüre Goethes?', Goethe-Jahrbuch, CVI (I989), 203-Io. For detailed accounts of the French, Latin, Dutch, German and English branches of the Reynard the Fox tradition before Goethe, see Hubertus Menke, Die unheilige Weltbibel: der Lübecker Reynke de Vos (1498-1998), Kiel, I998; Karl Werner, 'Reineke Fuchs: Burgundischer Ursprung eines europäischen Tierepos', Zeitschrift für deutsches Altertum, cxxiv (I995), 375-435; Christian Scheffler, 'Die deutsche spätmittelalterliche Reineke-Fuchs-Dichtung und ihre Bearbeitungen bis in die Neuzeit', in Aspects of the Medieval Animal Epic, ed. by Edward Rambauts and Andries Welkenhuysen, Leuven, I975, pp. 85-IO4.
} 
sources. He later referred to his 'zwischen Uebersetzung und Umarbeitung schwebende Behandlung' (FA, i, XvII, 24), a comment which hardly seems to justify inclusion of the epic within his original works.

For some of Goethe's readers, this mystery of the 'schwebende Behandlung' posed a challenge. Comparing Goethe's version with Gottsched's, Wilhelm von Humboldt notes with surprise:

Im einzelnen hat er fast nichts abgeändert, oft dieselben Worte gelassen, aber dennoch ist das Ganze durch ihn schlechterdings etwas anderes geworden. [...] Wodurch Göthe dieß bewirkt hat, ist schwer zu bestimmen, und ich habe an einzelnen Stellen vergeblich darüber gegrübelt. Das Silbenmaß, das es dem Griechischen näherbringt, tut viel, aber da es so äußerst lose und leicht behandelt ist, auch wieder nicht. Die Hauptsache liegt wohl in der Sprache, in dem Periodenbau, endlich und vorzüglich in der Behandlungsart des Genies, die sich nicht einzeln und mit Worten bestimmen läßt. ${ }^{2}$

Unable to determine precisely how Goethe's 'Behandlungsart' could turn Gottsched's translation into 'schlechterdings etwas anderes', Humboldt resorts to explaining the process with reference to Goethe's 'Genie', a force that transcends mundane analysis.

Humboldt's response accords with central paradigms of Goethe research. There is broad agreement that Reineke Fuchs may be read as a classical work imbued by a 'heiter-distanzierende Atmosphäre', in which Goethe came to terms with the bitter experience of the French Revolution. ${ }^{3}$ On the one hand, Reineke Fuchs has been described as a therapeutic exercise during the siege of Mainz in I $793 .{ }^{4}$ On the other hand, some interpreters equate Goethe's critical response to the revolutionary upheavals with the satirical 'mundus perversus' of Reineke Fuchs in contrast to the author's own affirmative socio-political credo, which is commonly identified with some newly introduced lines of the eighth canto $^{5}$ (VIII, I $\left.52-60\right)^{6}$. However, too little attention is generally paid to the concrete textual differences that distinguish Goethe's Reineke Fuchs from earlier texts; thus, the fact that Goethe radically reduced the polemics against nobility and clergy which he found in his sources has gone unnoticed (G 457, 20-2 $\mathrm{I}^{7} / \mathrm{XII}, 296-97$; G 46I, 7-24/XII, 336-37). Moreover,

\footnotetext{
${ }^{2}$ To Schiller, 27 February I796; Friedrich Schiller, Schillers Werke: Nationalausgabe, ed. by Julius Petersen and others, Weimar, I943-I967, xxxvi/I, I3 I-32.

${ }^{3}$ Lothar Schwab, Vom Sünder zum Schelmen: Goethes Bearbeitung des Reineke Fuchs, Frankfurt/Main, I97I, p. I30. For the continuity of this view, see also Emil Staiger, Goethe, Zurich, 3rd edn, I962, II, Ioo-O I, Diether Krywalski, 'Reinhart - Reineke Fuchs: Wirkungsgeschichte und Rezeption: Überlegungen zu einer Unterrichtssequenz in der I I. Jahrgangsstufe', Blätter für den Deutschlehrer, Xxx (I986), I-2 I and 53-57 (pp. I7, 56), and Roger Stephenson, 'The Political Import of Goethe's Reineke Fuchs', in Reynard the Fox: Social Engagement and Cultural Metamorphoses in the Beast Epic from the Middle Ages to the Present, ed. by Kenneth Varty, New York, 2000, pp. I9I-207 (p. I92).

${ }^{4}$ See Hans-Wolf Jäger, 'Reineke Fuchs (I794)', in Goethes Erzählwerk: Interpretationen, ed. by Paul Lützeler and James McLead, Stuttgart, I985, pp. I03-33 (p. II I).

${ }^{5}$ In the following, Roman and Arabic numerals without further bibliographical details refer to the cantos and lines of Goethe's Reineke Fuchs as published in volume i, viII of the Frankfurter Ausgabe (FA).

${ }^{6}$ See Klaus Lazarowicz, Verkehte Welt: Vorstudien zu einer Geschichte der deutschen Satire, Tübingen, I963, pp. 257303 (p. 298), Hubertus Menke, 'Zuvor niemals also gedruckt: Das (hoch-)deutsche Erfolgsbuch vom Reineke Fuchs', Philobiblion, XuIv (2000), I 86-2 I2 (pp. I95-98), and Herbert Kolb, 'Nobel und Vrevel: Die Figur des Königs in der Reinhart-Fuchs-Epik', in Virtus et Fortuna: Zur deutschen Literatur zwischen 1400 und 1720, ed. by Joseph Strelka and Jörg Jungmayr, Frankfurt/Main, I983, pp. 328-50 (pp. 328-35).

${ }^{7}$ Subsequently, I shall use 'G' to refer to Goethe's major source, the Gottsched edition of Reineke der Fuchs, in Gottsched, Ausgewählte Werke, ed. by Joachim Birke and Brigitte Birke, Berlin, I968-, IV.
} 
apart from Goethe's alleged 'political credo', which is put into the mouth of a protean traitor who wilfully attacks the order of King Nobel's court, indicators of a contrasting political ideality cannot be established within the text beyond doubt.

I propose to argue that in Reineke Fuchs, Goethe does not distance himself from a challenging reality, but subversively engages with fundamental discursive aspects of his time and the tradition of poetics in particular. Furthermore, Goethe's later selfexegeses in autobiographical writings such as Campagne in Frankreich (I822) and Tagund Jahreshefte (I822-25) promulgate a view of Reineke Fuchs by means of which Goethe endeavours to establish himself as a poet of natural genius and as a master of those 'Welthändel' (FA, iii, II, 665) that affected him on a much deeper level in I793 than he was willing to admit in the I820s. It will consequently be an initial aim of the following investigation to show that Humboldt misjudged Goethe's contribution to the tradition: Goethe did much more than merely transform Gottsched's prose into hexameters; rather he reshaped the syntactical and lexical structure in a way that left 'almost nothing' unmodified. Despite isolated attempts at comparison, the systematic nature of Goethe's modifications and their far-reaching implications have not been explored. Goethe's alterations caused significant disturbances in the entire literary field of the German epic, as the contemporary reception of Reineke Fuchs demonstrates. The destabilizing effect of Reineke Fuchs was not just directed backwards at the antediluvian authority of Gottsched. At stake was the question of authority in German literature as such. Recent criticism has noted the ambiguity of Goethe's version without, however, recognizing its textual basis and strategic force. ${ }^{8}$ I shall seek to establish that this ambiguity of response is by no means incidental but a structural characteristic of Goethe's adaptation, whose rhetoric generates ambiguity at every turn.

Although the significance of speech and rhetoric in Goethe's text has received extensive comment, attention has focused exclusively on the eloquence of the protagonist. In fact, Goethe makes a number of changes, omissions and additions in order to endow nearly every animal character of his poem with remarkable rhetorical talents. A comparative reading reveals that rhetoric is distributed in a way that undermines any clearly identifiable ethical proposition. The problematic function of rhetoric is suggested in the metaphors of 'Mischen' and 'Sondern', which Goethe introduces at the very end of Reineke Fuchs, in the only explicit poetological reflection in the entire work. The significance of these verbs emerges from a close comparison of Goethe's version with Gottsched's translation:

Deswegen ist dieß Buch geschrieben: das ist sein Sinn, und anders nichts. Fabeln und solche Gespräche, werden zu unserer Lehre aufgesetzt, damit wir die Untugend meiden, und $\mathrm{zu}$ allen Zeiten Weisheit lernen sollen. (G 467, I9-2I)

\footnotetext{
${ }^{8}$ See, for instance, Gerhard Kluge, 'Der Schelm — ein Ästhet: Zu Goethes Reineke Fuchs', in Das Schöne soll sein: Aisthesis in der deutschen Literatur, ed. by Peter Heßelmann, Bielefeld, 200I, pp. 193-204 (p. I95), and Hubertus Menke, 'Schurke, Schelm und rebellischer Held: Die Wandlungen der Reineke-Fuchs-Auffassung', in Geschichtlichkeit und Aktualität: Studien zur deutschen Literatur seit der Romantik, ed. by Klaus-Detlef Müller and others, Tübingen, I988, pp. I-I2 (pp. 9-IO).
} 
Dieses ist der Sinn des Gesangs in welchem der Dichter

Fabel und Wahrheit gemischt, damit ihr das Böse vom Guten

Sondern möget, und schätzen die Weisheit [...] (XII, 373-77)

Both the strategies of omission and replacement are essential clues to Goethe's project. He omits Gottsched's 'Gespräche', the double layers of moralizing commentaries, and introduces 'Wahrheit' as a complement to 'Fabel', now in the singular, thereby filling the gap with a key concept of philosophical discourse. Furthermore, 'Fabel' can also be understood as narrative 'plot', which the contemporary aesthetic discourse differentiates from 'würkliche Geschicht'. In this context Goethe's final lines gain another, less harmonious sense, as they open up an antithesis between literary virtuality and the category of truth: if 'Fabel' and 'Wahrheit' can be mingled, does this not assume their prior independence? The reference to the exemplary function of fables as mirrors of virtue and vice draws on a didactic register largely lacking in the foregoing text, and this question, like the whole passage, therefore remains ironically suspended.

Goethe's substitution of 'Wahrheit' for 'Gespräche' situates the text in an ongoing debate about the essence and function of literary rhetoric in the eighteenth century, in which the polarity of veracity and verisimilitude is a key issue. Literary production and critical philosophy here part company. I would like to suggest that the seemingly incidental replacement of 'Gespräche' by 'Wahrheit' should be read as an indication of a more general displacement of rhetoric, and that the change of metaphor introduces the structural leitmotif of this displacement. Whereas the poet's work of narrative fiction engages in 'Mischen' of 'Fabel' and 'Wahrheit', the reader is to respond by separating ('Sondern') ethical categories. The poetics of 'Mischen' and 'Sondern' in Reineke Fuchs both invite and undermine the mode of allegorical reading that had dominated the literature of the eighteenth century. This destabilization may be seen as an instance of that disturbance of the cognitive field, of receptive conventions and of classical rhetorical structures, which Paul de Man's deconstructive approach addresses. For de Man, a structure of language

becomes rhetorical not when we have, on the one hand, a literal meaning and on the other hand a figural meaning, but when it is impossible to decide by grammatical or linguistic devices which of the two meanings (that can be entirely incompatible) prevails. Rhetoric radically suspends logic and opens up vertiginous possibilities of referential aberration. ${ }^{10}$

Among Goethe's alterations of Gottsched's model, gnomic phrases and rhetorical questions are prime sources of this kind of rhetorical polysemia. For example, in Gottsched Reineke responds with an unambiguous rhetorical question when King Nobel is tempted by last doubts about Reineke's disclosure of a potential conspiracy

\footnotetext{
${ }^{9}$ See Johann Georg Sulzer, Allgemeine Theorie der Schönen Künste, Leipzig, I77I-74, I, 359-60; see also Gottsched's definition of 'Fabel': 'eine unter gewissen Umständen mögliche, aber nicht wirklich vorgefallenen Begebenheit'; Versuch einer Critischen Dichtkunst, in Gottsched, Ausgewählte Werke, vI/I, 204.

${ }^{10}$ Paul de Man, 'Semiology and Rhetoric', in de Man, Allegories of Reading: Figural Language in Rousseau, Nietzsche, Rilke, and Proust, New Haven, I979, pp. 3-20 (p. Iо).
} 
against him: 'Was würde es mir helfen, daß ich mich dergestalt selbst verdammete? Ihr seht ja wohl, wie es nun mit mir steht. Sterben muß ich nun, das ist gewiß' (G I96, 30-I97, 2). Reineke, still sentenced to death, worms his way into Nobel's confidence by tacitly insinuating that he would not abuse his last confession by the deadly sin of lying. By a slight grammatical modification Goethe forms the same passage into a gesture of self-questioning and answering:

Könnt' es mir nützen, wenn ich euch löge? Da würd ich mich selber

Ewig verdammen. Ihr wißt ja nun wohl, so ist es beschlossen,

Sterben muß ich, ich sehe den Tod und werde nicht lügen [...] (IV, 29I-93)

Whereas Gottsched's question permits only one answer and the final question mark could equally be replaced by an exclamation mark, Goethe's grammatical change makes the phrase dangerously equivocal. Taken as a rhetorical question, it still articulates the aporia of one who will inevitably be given the death sentence. However, Reineke's open question also permits the answer that lies might well help, provided they are convincing enough to lure an inconstant monarch into rescinding the sentence. Goethe's modification of the grammatical surface undermines the scheme of figurality and literality as a distinctive model of 'Wahrheit' and 'lügen' (IV, 290/293) in the context of this passage; it is impossible to decide whether a figurative or a grammatical reading prevails and impossible to dispel the contradictory possibilites at this first crucial juncture of the poem. Drawing on de Man's insights into the irreducibility of figural polysemia, I shall demonstrate that the poetics of 'Mischen' and 'Sondern' are a fundamental aesthetic principle in Reineke Fuchs, which constitute a fundamental strategy of resistance to established tradition.

Reineke Fuchs 'der listige Redner' ( $\mathrm{x}, \mathrm{I}$ ) is an orator of outstanding ability. Roughly seventy-one per cent of Goethe's poem consists of juridical, deliberative or epideictic speeches. Moreover, the speeches play an important role in the narrative, as Goethe's narrator deliberately masks important facts and obscures the relationship between culprits and victims. The matter of the rape trial, for instance, is blurred from the outset due to a mutual sexual desire between Reineke and the she-wolf (III, 94-95). Even when Reineke admits adultery explicitly, it remains unclear whether lady Gieremund's shame is due to the rape or to Reineke's indiscretion:

Weiter bekenn ich vor euch: daß ich Frau Gieremund heimlich

Öfters besucht und öffentlich auch, das hätte nun freilich

Unterbleiben sollen, o, wär' es niemals geschehen!

Denn so lange sie lebt verwindet sie schwerlich die Schande. (III, 384-87)

Außer dem habe ich auch mit seinem Weibe, der Frau Gieremuth, Dinge getrieben, davon ihr Schimpf und Unehre zugewachsen, und die sie langsam verwinden wird: wiewohl ich wünschte, daß es unterblieben wäre. (G I60, 34-I6I, 2)

Instead of confessing to a moral crime, Reineke uses a euphemistic litotes ('besucht') to display an emphatic respect for public ('öffentlich') moral decency. Trickster that he is, Reineke similarly turns the tables against his other accusers again and again, and Goethe supports this by significant changes with reference to the ethos of the litigants. 
In the rhetorical treatises that were canonical for the eighteenth century such as Quintilian's Institutio oratoria (v, 8, 3; XII, IO, 59) or Cicero's De oratore (xxI, 69), speech either 'proves' by arguments or 'persuades' by moving the emotions. The ethos of the orator, exhibited in his words and habits of speaking, contributes to the latter strategy by arousing a gentle emotion of sympathy towards a good character: 'Sic proderit plurimum causis, quibus ex sua bonitate faciet fidem'. ${ }^{11}$ Conversely, ethos can also be a source of objections against the trustworthiness of an opponent. After Goethe's revision, the animal orators in Reineke Fuchs make use of this strategy to a confusing extent. When Reineke delivers his first confession in face of the gallows, he starts off with a striking captatio benevolentiae:

Erst, ich war noch ein kleiner Kompan, und hatte die Brüste

Kaum zu saugen verlernt, da folgt' ich meinen Begierden

Unter die jungen Lämmer und Ziegen, die neben der Herde

Sich im Freien zerstreuten; ich hörte die blökenden Stimmen

Gar zu gerne, da lüstete mich nach leckerer Speise. (Iv, 202-06)

Where Gottsched had 'Bube', which still connoted wickedness in the late eighteenth century, Goethe picks up the noble archaism 'Kompan' from the older Lübeck source in order to invoke an idyllic childhood scene, in which sweet little Reineke does not attack the livestock 'immer dreister und kühner' (G I 89, 30), but merely practises (IV, 209: 'übte mich') with pleasure on 'Lämmchen' (IV, 207) as a sort of education of taste: 'es schmeckte mir köstlich' (IV, 208). These slight changes contrast Reineke with the wolf Isegrim, whom Reineke now depicts as a cruel and decadent child abuser:

Wenn er ein Kalb sich geraubt, sich einen Widder erbeutet,

Wenn ich im Überfluß sitzen ihn fand, er eben die Ziege

Frisch geschlachtet verzehrte, ein Bock ihm unter den Klauen

Lag und zappelte, grinst er mich an und stellte sich grämlich,

Trieb mich knurrend hinweg, so war mein Teil ihm geblieben. (Iv, 224-28)

One of Goethe's most striking techniques is that of transference, which draws on the rhetorical topos of turning upon the opponent what could be said against oneself. In order to promote themselves and their claims, the animals characterize themselves by quasi-human attributes, whilst the opponent is denounced as bestial (x, 36I-66) - in Reineke's account, Isegrim drives him away 'knurrend' (Iv, 228; G I90, io: 'fuhr mich sehr an').

Without batting an eyelid, Reineke lumps his opponents together as 'lose Verräter' (IX, I4I) and assigns to them the hypocrisy attributed to him both by the narrator and Reineke's adversaries; he usurps the scruples of Hinze the cat about a potential ambush during their mouse raid (III, 66) and later professes even to have warned him 'treulich' (IV, 43). Sly enough to adapt his style of speech to any predominant discourse, he remembers his prey 'zärtlich' (XI, 440) to ingratiate himself with sentimental King Nobel. Nor does he hesitate to declare his crimes against the

\footnotetext{
${ }^{11}$ Marcus Fabius Quintilian, Institutio Oratoria/The Orator's Education, ed. and trans. by Donald Russell, Cambridge, 200I, VI, 2, I 8 .
} 
other animals as a good deed: 'So verhüt' ich zuletzt noch manches Übel und hoffen | Kann ich, es werde mirs Gott in allen Gnaden gedenken’ (IV, I93).

It has been suggested that Reineke's rhetorical talent does not just express 'a positive, life promoting, indeed enlightening' ideal with a touch of 'aesthetic flair', but that even beyond these effects of docere and delectare, Goethe endows Reineke with the ethical responsibility of Quintilian's vir bonus dicendi peritus. ${ }^{12}$ Individual passages viewed in isolation might indeed seem to accentuate Reineke's virtues. For example, when all his enemies bombard Reineke 'mit heftigen Reden' (IV, 74) on his first entrance at court, he displays an almost stoic aequitas animi:

Reineke stand und wußte darauf gar künstlich zu dienen:

Denn ergriff er das Wort, so floß die zierliche Rede

Seiner Entschuldigung her, als wäre es lautere Wahrheit. [...]

Hörte man ihn, man wunderte sich und glaubt ihn entschuldigt,

Ja, er hatte noch übriges Recht und vieles zu klagen. (IV, 79-83)

Goethe replaces Gottsched's ‘schönste Antworten' (G I78, 33) by 'künstlich' and 'zierliche Rede' and, the newly introduced metaphor of gentle fluency ('floß') also brings about a reversal of positions and rights. Goethe stresses that Reineke's words make him appear honourable ('glaubt'). Even outside the trials Goethe stigmatizes Reineke's rhetoric as dubious, artificial and devouring. Thus, we are given revealing insights into his castle Malepartus, the place where Reineke seeks his arguments and ideas:

[...] Er ging in die Tiefe der Wohnung,

In die Winkel des Schlosses, denn künstlich war es gebauet.

Löcher fanden sich hier und Höhlen mit vielerlei Gängen,

Eng und lang und mancherlei Türen zum öffnen und schließen,

Wie es Zeit war und Not. Erfuhr er, daß man ihn suchte

Wegen schelmischer Tat, da fand er die beste Beschirmung.

Auch aus Einfalt hatten sich oft in diesen Mäandern

Arme Tiere gefangen, willkommene Beute dem Räuber. (II, 23-30)

The equivocal adjective 'schelmisch' figures as a leitmotif for the 'Paarung von Verbrecher- und Künstlertum' that Reineke represents. ${ }^{13}$ In contrast to Gottsched and the Dutch tradition, in Goethe's poem Reineke inhabits not a gloomy den, but a 'Schloss' which resembles both a Rococo residence with secret doors and an artificial labyrinth. Malepartus may be read as an allegory of Reineke's mind, but also of his rhetorical invention, which is characterized by reception rather than creative originality. ${ }^{14}$ The animals that Reineke seizes 'verrätherischer Weise' in Gottsched's account (G I05, 35) are now 'willkommene Beute', which not only means that they are animal prey, but also alludes to intellectual profit or copia rerum, the fruits of a wide learning and erudition. Goethe's Reineke shows the traits of

\footnotetext{
${ }^{12}$ Roger Stephenson, 'The Ethical Basis of Goethe's Reineke Fuchs', in Goethe at 250: London Symposium/Goethe mit 250: Londoner Symposium, ed. by T. J. Reed, Martin Swales and Jeremy Adler, Munich, 2000, pp. 265-73 (pp. 270-7I). For the significance of ethical responsibility in classical rhetoric see Quintilian, Institutio Oratoria, XII, I, I-7.

${ }^{13}$ Schwab, Vom Sünder zum Schelmen, p. 43.

${ }^{14}$ See Friedrich Georg Jünger, Über das Komische, 3rd edn, Frankfurt/Main, I948, p.59.
} 
'ein Gelehrter' (III, I99), who knows well how to improvise a speech and please his audience with reference to a wealth of fables and myths from antiquity to the middle ages: 'Gerne hörte es der König und fiel in allem und jedem | Reineken bei, er hatte die Lüge so künstlich geflochten' (x, 46I-62; my emphasis).

What further blurs the ethical meaning of Reineke Fuchs is the fact that Reineke is by no means the only master of tropes and figures, of 'listige Wendung', a term closely associated with the topic of lying throughout the poem (III, 2 I 2; IV, I 82; V, I-3; VI, 2I3; XII, 289) - many of the other animals are, too. Not only his allies such as Frau Rückenau the ape (IX, I 87-95), but even Reineke's adversaries such as the 'gesprächige Krähe' Merkenau (IX, 50) use rhetorical figures and topoi in order to turn their accounts into more general ethopoietic fictions about the disgraceful character of their opponent:

\section{[...] Nun höret das Unglück.}

Wie sie [Frau Scharfenebbe] nun traurig und ohne Besorgnis dem Munde des Schelmen Ihren Schnabel näher gebracht, bemerkt' es der Unhold,

Schnappte grimmig nach ihr und riß das Haupt ihr herunter.

Wie ich erschrak, das will ich nicht sagen: O weh mir! o weh mir! (vII, 66-70)

Here Goethe intensifies Gottsched's moderate translation ('schnappte' for 'ergriff; 'riß herunter' for 'biß'; see G 270, I4) by deeply emotive invectives against the 'Unhold' Reineke, and this suggests that rhetoric itself is at stake in Reineke Fuchs. The technique of incriminating the opponent as a ferocious animal and conversely assuming anthropomorphic traits for oneself is not limited to Reineke, but available to all who refer to the power of speech in Reineke Fuchs. Even Goethe's narrator, who directs special attention to the power of rhetoric throughout the poem (V, I; VIII, 35), contributes to the twists and turns by breaking up established perspectives and values. Thus he subtly advocates the 'arme Tiere' (II, 30; III, I3 I) against Reineke the 'Heuchler' (v, 230) and 'Falscher' (VI, 296), and distances himself from Reineke the merciless fighter in the final duel by sympathizing with the mutilated Isegrim (XII, 74/G 44I, I8-I9).

Comparing Reineke Fuchs to the earlier narrative tradition, we can see Goethe shifting and balancing the charges throughout the narrative by means of his poetics of 'Mischen'. This also applies to the mixed style of the highly digressive speeches, a paradigmatic example of which is Reineke's second 'treasury speech' of the tenth canto. As in the first trial, Reineke uses his last words to escape into a realm of fiction, to flatter the royal judges and rouse their passion for wealth, to blame his accusers and so turn the tables on them. Reineke saves himself by an irrefutable ekphrasis on the mirror, comb and ring allegedly embezzled by Bellyn the ram. With eloquent cunning, he turns the retrospective admiration of the precious goods into glittering descriptions of the cabbalistic carvings of the gem, their protective powers, and the myths and fables engraved in the rim of the mirror. However, Goethe's Reineke employs this popular device of medieval narratology in order to construct an artificial and seductive enthymeme against his opponents. Not only the images of 'Seth der Fromme vom Paradiese' (x, 22), the Helena myth (x, 8I-IO9) and a fabulous horse (x, IO2-28) were depicted on the rim, Reineke recounts, but also the fables of the envious horse (x, I33-5I) and ass (x, I 52-86), and even an 
episode about Hinze cheating on Reineke's father (x, I87-2 I8) and two tales of an egoistical wolf (x, 219-43; 244-337). Implicitly, the legitimating force of the biblical and Homeric references strengthens an array of arguments which reaches from fables on moral commonplaces to humiliating aspects of his individual opponents Hinze and Isegrim, the latter playing the ignoramus in the concluding pig hunt (x, 352-408). Along with the shift of the subject, Goethe lets Reineke's rhetorical style soar to the pathos of the genus grande when Reineke laments Bellyn's betrayal, or when he alludes to religion to flatter the queen as a new Mary (x, 59 and 62). Reineke knows equally well how to win sympathy for his father by adding some epithets and metonymies of the genus medium typical of Voss's Homer (e.g. Reineke's father, 'der Alte' [x, 282] 'mit herrlichem Rate' [x, I96]), and he mocks Isegrim by means of the genus humile, when he ridicules the Isegrim's 'ängstlich' relative with a bone stuck in his throat $(\mathrm{x}, 224)$.

In addition to the mixture of narrative modes, Goethe mixes a variety of styles and rhetorical registers, which transform the performance of fictionality into a vast digression and move even his enemies and victims: 'Jedermann glaubt ihm [...] | Ja man sucht ihn zu trösten' (x, 442-44). Thus, Reineke's epithet 'Schelm' (I, I4) stands for an illness of figural language in general: ${ }^{15}$

Reineke hat mich betrogen! So rief der König. O hätt' ich

Seinen schändlichen Lügen nicht Glauben gegeben! so rief er, Schien verworren, mit ihm verwirrten sich alle die Tiere. (vi, 368-70)

However, this holds true not only for Reineke's 'Lügen', but also for the speeches in Reineke Fuchs in general. Grammatical indeterminacy and syntactical polyvalency of paratactical style, litotes, homonymies, sententiae instead of unambiguous arguments proper - these are the most frequent figural devices that set Goethe's Reineke Fuchs apart from its precursors. They contribute to an epic world of ambiguity, in which ethical values such as pity (XII, I48-49), mercy (XII, 288) or justice ${ }^{16}$ are but shifting discursive constructs on a utilitarian playground made slippery by the 'zerfließende Verse' of Goethe's hexameters. ${ }^{17}$

Recent studies have suggested that we should not underestimate the mixture of figural and grammatical dimensions in Reineke Fuchs as the trifling adornments of an 'Uebung im Hexameter', as Goethe later claimed (FA, i, XVII, 24). ${ }^{18}$ On the contrary, we are urged to investigate the poetological implications of these figural troubles as a response to contemporary discourses on animal literature and fables, the epic genre, and the quest for a German national literature, but also the

\footnotetext{
${ }^{15}$ See Johann Christoph Adelung, Grammatisch-kritisches Wörterbuch der Hochdeutschen Mundart, 2nd edn, Leipzig, I793-I80I, III, I4Io (s.v. 'Schelm'): 'eine ansteckende tödtliche Seuche'.

${ }_{16}$ Pointedly, where Gottsched had 'Recht', Goethe stresses Reineke's competence in 'Rat' (IX, 336).

${ }^{17}$ Ulrich Hötzer, "'Grata Negligentia” _ "Ungestiefelte Hexameter"? Bemerkungen zu Goethes und Mörikes Hexameter', Der Deutschunterricht, XVI (1964), 86-107 (p. 90). For a detailed analysis of Goethe's liberal use of enjambement and prose-like structures for the hexameters of Reineke Fuchs see Schwab, Vom Sünder zum Schelmen, p. I I3, Ernst Feise, 'Der Hexameter in Goethes Reineke Fuchs und Hermann und Dorothea', Modern Language Notes, L (I935), 230-37, and Waltraud Wiethölter, 'Zur Deutung', FA, i, viII, I I36.

${ }^{18}$ See Katrin Kohl, Friedrich Gottlieb Klopstock, Stuttgart/Weimar, 200o, pp. I I-22; Meredith Lee, Displacing Authority: Goethe's Poetic Reception of Klopstock, Heidelberg, I999, pp. I-44, and Kevin Hilliard, Philosophy, Letters, and the Fine Arts in Klopstock's Thought, Leeds, I987, pp. 68-I27.
} 
competition between 'rhetorical' and 'mimetic' concepts of poetry. In each of these discourses Goethe's text proves subversive of poetic traditions and authorities.

As regards the genre of the fable, the concluding appeal to the reader to 'separate' ('Sondern', XII, 377) invites us to read Reineke Fuchs in relation to the theory of allegory. By retaining elements such as Phaedrean fables (e.g. X, I33-5I) and the patristic Physiologus tradition (e.g. x, 66-78), Goethe alludes to an incongruous range of concepts of allegory. It is useful here to recall Quintilian's definition of allegory as duplicating transference: 'Allegory, which people translate inversio, presents one thing by words and either a different or sometimes even a contrary thing by its sense'. ${ }^{19}$ For Quintilian, allegory is the fundamental model for the addition of figural to literal meaning (VIII, 6, I). As Quintilian's concept of allegory is grounded in the arbitrariness of the relationship between 'verbum' and 'res', it can even comprise the extreme case of 'contrarium', the opposition of literal and figural meaning.

In this context, we can observe a general shift of the concept of allegory in the eighteenth century, especially in relation to the fable. While Le Bossu had defined fables as 'instructions deguisées sous les allegories d'une action' ${ }^{20}$ and thus stressed the esoteric concept of allegory as a structure in need of hermeneutic work, a century later Lessing reformulated the allegorical fable in terms of Wolffian cognitio intuitiva:

In der Fabel wird nicht eine jede Wahrheit, sondern ein allgemeiner moralischer Satz, nicht unter die Allegorie einer Handlung, sondern auf einen einzeln Fall, nicht versteckt oder verkleidet, sondern so zurückgeführt, daß ich, nicht bloß einige Ähnlichkeiten mit dem moralischen Satze in ihm entdecke, sondern diesen ganz anschauend darin erkenne. ${ }^{21}$

In Reineke Fuchs, by contrast, Goethe not only strings together extended sequences of fables and exemplary narratives whose meaning is by no means clear and 'ganz anschauend', but also withholds a framing commentary. Reineke's reference to the myth of Troy in the tenth canto is a typical example, for it concludes with perplexing vagueness:

Und er gab ihr den Apfel und pries sie von allen die schönste,

Aber sie half ihm dagegen die schöne Königin rauben,

Menelaus Gemahlin, sie ward in Troja die Seine.

Diese Geschichte sah man erhaben im mittelsten Felde.

Und es waren Schilder umher mit künstlichen Schriften, Jeder durfte nur lesen, und so verstand er die Fabel.

Höret nun weiter vom Spiegel! [...] (x, IO6-I2)

Can we really understand 'die Fabel'? Of course, the judgement of Paris is a classical topos, but as the context of Reineke Fuchs presents the narrative as a fable, we are faced with a 'Leerstelle', a blank line where Gottsched's edition has an explicit

\footnotetext{
${ }^{19}$ Quintilian, Institutio Oratoria, viII, 6, 44.

${ }^{20}$ René Pierre Le Bossu, Traité du poème épique, La Haye, I675, p. 23.

${ }^{21}$ Gotthold Ephraim Lessing, 'Abhandlung über die Fabel', in Lessing, Werke, ed. by Herbert Göpfert, Darmstadt, I970-79, v, 379.
} 
moral (G 360, 26-36I, 38). In Goethe, the judgement of Paris resembles a spolia in architecture, a fragmented piece still strangely jutting out from the narrative context, as it can be associated with the narrative in a number of ways without being fully integrated. Does Reineke allude to the initial adultery of Helena as a prolepsis of his later accusation of the adulterous Gieremund? Or is it meant as a flattering eulogy for the listening queen - the beauty of Helena is emphasized (x, I07) and an example of 'Standesdichtung'? Or does Reineke simply use the legitimizing function of the mythological narrative to strengthen his position against the narratives of his opponents? It is hard to exclude any of these possibilities, and so we are confronted with indeterminacy.

According to a common view in Goethe research, Goethe's treatment of allegorical structures in Reineke Fuchs mirrors the shift towards a symbolic concept of poetry, which is traditionally regarded as the fruit of his Italian journey. ${ }^{22}$ However, this totalizing claim is problematic insofar as it conceals the semiotic indeterminacies in passages such as that quoted above. It is important to note that the abundant glosses of the I 498 Reynke de Vos had fragmented the main narrative into short episodes that served as springboards for an encyclopedic commentary on religious and secular morality. As Ralf-Henning Steinmetz has pointed out, these commentary passages had an organizing function and fulfilled a primary role. ${ }^{23}$ They interrupted the narrative to build and rebuild acts of allegoric signification, which could even assign heterogeneous if not contradictory evaluations to actions and characters. Thus, Gottsched's version presented Reineke as an example of both confidentia and temptatio even in the same gloss (G I80, 6- I3). As Goethe's text abandons these glosses, quite a different and disturbing process emerges. Reineke Fuchs, Isegrim and King Nobel are no longer vehicles of dynamic signification but become imaginable characters. Reineke cannot be read as an animal mask fronting human knowledge of rhetoric and classical mythology or Goethe's political views - or, conversely, as a superficially anthropomorphized animal. The loosening and yet counter-balancing, ambiguating tendency of his alterations and omissions suggests that Goethe disquietingly allows both tendencies to interact. It is significant in this context, that he did not use any pictorial devices in his Reineke Fuchs, which might have cancelled the oscillation between literal and figural dimensions of actions, characters and speeches — even though he admired the etchings of Allart van Everdingen reprinted in Gottsched's edition of 1752 . We can thus read the figural troubles in Reineke Fuchs as signs of a crisis in the concept of allegory as Quintilian had understood it — as a precarious use of figural language that exposes the instability and unreliability of rhetorical discourse.

Furthermore, by replacing Gottsched's 'Gespräche' (G 467, I9) with 'Wahrheit' (XII, 376) in the epilogue of Reineke Fuchs, Goethe relates his poem to the dispute

\footnotetext{
${ }^{22}$ See Schwab, Vom Sünder zum Schelmen, pp. I28-36. For the distinction between allegory and symbol in Goethe's thought, see Bengt Algot Soerensen, 'Die "zarte Differenz" — Symbol und Allegorie in der ästhetischen Diskussion zwischen Schiller und Goethe', in Formen und Funktionen der Allegorie, ed. by Walter Haug, Stuttgart/Weimar, I979, pp. 632-42, and Klaus Vogel, Das Symbolische bei Goethe: Begriffs- 'Bilder' des Scheinens, Munich, I997.

${ }^{23}$ See Ralf-Henning Steinmetz, 'Reynke de Vos (I 498) zwischen Tierepos und kommentierter Fabelsammlung', in Vulpis Adolatio: Festschrift für Hubertus Menke, ed. by Robert Peters, Horst Pütz and Ulrich Weber, Heidelberg, 200I, pp. $847-59$.
} 
between rhetoric and philosophy which polarized eighteenth-century discourse on poetry. A philosophical model of literary aesthetics centred on the Aristotelian concept of art as mimesis, while a rhetorical conception foregrounded rhetorical skill, competition and literary tradition as integral aspects of poetry. One of the most influential advocates of the latter, Friedrich Gottlieb Klopstock, remained an important figure in Goethe's thought and writing far beyond the rift in their personal relationship in I776. In particular Klopstock's Messias remained an important work in the field of the German hexameter epic, in which Goethe situated Reineke Fuchs. It is seriously reductive, however, to see in Goethe's Reineke Fuchs a 'metrical exercise to drive out any residual association between the meter and the religious strains of Klopstock's epic'. ${ }^{24}$ For Goethe's alterations rather seek a subtle intertextual dialogue with Klopstock's Messias from the very first lines:

Pfingsten, das liebliche Fest, war gekommen, es grünten und blühten

Feld und Wald; auf Hügeln und Höhn, in Büschen und Hecken

Übten ein fröhliches Lied die neuermunterten Vögel;

Jede Wiese sproßte von Blumen in duftenden Gründen,

Festlich heiter glänzte der Himmel und farbig die Erde. (I, I-5)

Goethe enriches the conventional invocation of nature found in his sources by means of vocabulary that gives the Pentecost cosmic dimensions. He thereby refers to the same metaphors of radiance and colourfulness Klopstock had used to illuminate the relation between the divine Creator and his creation in the first canto of the Messias. When God comes 'vom Himmel herab' (I, 35), ${ }^{25}$ the earth resounds ('Unter ihm tönte die Erde'; I, 73) and the hills shine 'in lieblicher Abenddämmerung | Gleich als blühten sie wieder' (I, 80-8I). In Klopstock's epic metaphors of radiance (I, 89, 203, 706) and colour (I, 206, 207, 636) express the emanation of the divine and the presence of the Saviour. When Jesus falls asleep at the Mount of Olives, his lineaments resemble 'der blühenden Erde | Halbunkenntliches Antlitz an Frühlingsabenden' (I, 54I-42). Goethe's last line reformulates the modest statement 'Der Tag war heiter, und das Wetter schön' (G 77, 9-Io) of his Gottschedian source with reference to Klopstock's 'der Feyer | Festlicher Glanz' (Messias, I, 705-06; I74-75) flowing down from Gabriel's feet. Although Goethe obviously invokes Klopstock's tone - including lexical extravagancies ('neuermuntert') - he omits Klopstock's metaphysical dimension. Whereas the iridescent rainbow figured in Klopstock as an image of mediation between heaven and earth, Goethe attaches the colours exclusively to the latter. This ambivalent gesture of reference to and abandonment of Klopstock's narrative model is a recurrent feature of Reineke Fuchs. One of the most striking examples concerns Reineke's confidence in the aura of his oratory before King Nobel:

[...] Und hätt ich noch zehnmal Mehr verbrochen, so weiß ich es schon, so bald mir's gelinget, $\mathrm{Ihm}$ in die Augen zu sehen und ihn zu sprechen, so fühlt er Seinen Zorn im Busen bezwungen. [...] (III, 222-25)

\footnotetext{
${ }^{24}$ Lee, Displacing Authority, p. 40.

${ }^{25}$ Subsequent quotations of Klopstock's Der Messias refer to volume IV of the Hamburger Klopstock-Ausgabe: Der Messias, ed. by Elisabeth Höpker-Herberg, Berlin/New York, I974-I999.
} 
This passage modifies the source in significant ways. Gottsched has Reineke aspiring to see King Nobel 'unter die Augen' (G I46, 5-6), a phrase that in the eighteenth century simply denoted the presence of a person. By contrast, Goethe's fox uses his glance as a powerful means of influence. Accordingly, it is not the King who suppresses his own wrath $(\mathrm{G} \mathrm{I} 46,7)$, but Reineke's charisma and speech that overcome him ('fühlt er | Seinen Zorn bezwungen'). As Kevin Hilliard has shown, looks and glances figure as significant threshold devices of trans-verbal communication in Der Messias, when Jesus impresses Pilate and Herod (VII, I36-37, 248, $58 \mathrm{I}-9 \mathrm{I}$ ), or gives detailed commands to the seraphim (VII, 83I-32); equally Satan and Adramelech are banished from the Cross by Eloa's 'herrschender Blick' (viII, I46). ${ }^{26}$ Goethe's subtle reference to this silent rhetoric of 'in die Augen sehen' opens up a comparative perspective, in which Klopstock's Jesus is paralleled by Goethe's fox. But whereas the silencing of speech in Klopstock's hymns and Der Messias reflects fundamental theological dimensions of language, Goethe stresses that there is nothing in heaven and earth that could silence Reineke's 'Schwätzen und Schmeicheln' (IV, 23). However, these and other references to Klopstock and the religious discourse of the Messias such as Reineke's passio (IV, 95-97) or the 'fröhliche Botschaft' (I, 233) about his seeming conversion should not be narrowed down to an explicit parallel of narrative lines or to a strident antagonism of Reineke Fuchs and Klopstock's Messias. On the contrary, Reineke Fuchs should be viewed in the context of other epic writings by Goethe such as Hermann und Dorothea and the fragmentary Achilleis. For it shares with them a technique of detailed references to ancient and contemporary epic models while at the same time distancing and 'isolating' recast elements and motifs. ${ }^{27}$ Thus, even scattered references suffice to invoke the intertextual perspective in Reineke Fuchs and to direct its problematic staging of rhetorical language against Klopstock's hypotext. In the context of the general shift in Goethe's work from a positive assessment of rhetoric and writing as a craft towards a self-assured concept of poetry that insists on uncontestable 'persönliche Würde des Dichters' (FA, i, XIV, 856) and natural talent, Reineke Fuchs may be read as another stage of a subliminal debate with Klopstock. The figural troubles and rhetorical aporias of Reineke Fuchs subvert a rhetorical concept of poetry by increasing to a strategy of rhetorica contra rhetoricam that empties the text of any homiletic residue. ${ }^{28}$ Goethe turns the moral lessons of the Reynard the Fox tradition into a free-floating ensemble of speeches on ethical issues. When the author ironically recommends in a letter of 7 June 1793 that his pious friend Jacobi should read Reineke Fuchs in den gewöhnlichen Betstunden' (FA, ii, III, 675), we see another glimpse of this subliminal attack on the literary space which was even in the I790s associated with Klopstock's Messias.

However, Goethe's scepticism concerning rhetoric in Reineke Fuchs marks not only an attempt to free himself from the authority of Klopstock (for whom he was

\footnotetext{
${ }^{26}$ See Hilliard, Philosophy, Letters, and the Fine Arts in Klopstock's Thought, pp. 9I-I I I. On speaking and silencing in Klopstock as a 'Gestalt einer sowohl existentiellen als auch sprachlichen Grenzerfahrung', Kevin Hilliard, 'Schweigen und Benennen bei Klopstock und anderen Dichtern', in Das Erhabene in der Dichtung: Klopstock und die Folgen, Halle, I997, pp. I3-33 (p. 23).

${ }^{27}$ See Dieter Martin, Das deutsche Versepos im 18. Jahrhundert: Studien und kommentierte Gattungsbibliographie, Berlin/ New York, I993, pp. 247-3 I5.

${ }^{28}$ On the tradition of criticism of rhetoric by means of rhetoric see Klaus Dockhorn, Macht und Wirkung der Rhetorik: Vier Aufsätze zur Ideengeschichte der Vormoderne, Bad Homburg, I968, pp. 93-95.
} 
even occasionally mistaken during the French campaign, FA, ii, III, 64I). It may also be related to Goethe's scepticism about the rhetorical nature of a stereotypical discourse on politics, as expressed in a letter to Jacobi of I 8 August I792 (FA, ii, III, 623). Furthermore, it is accompanied by polemical sideways glances at other contemporary epic writings and not least by a resistance to the discourse of German philology. ${ }^{29}$

By Goethe's day, the reception of the Reynard tradition had split into two opposed branches. On the one hand, popular prose versions ('Volksbücher') of Reineke Fuchs, mostly descending from High German translations in the spirit of Georg Philipp Harsdörffer (I650; I662), were popular among the lower and middle classes and especially acclaimed by young readers and women, a readership

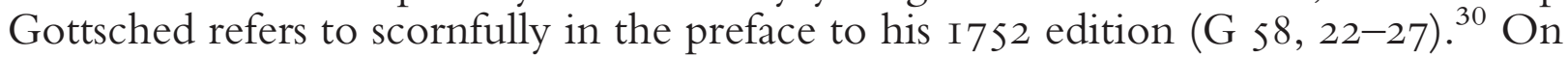
the other hand, Reineke had become a prime concern of an enlightened philology in search of the authentic roots of German culture. Dismissing the popular adaptations, advocates such as Friedrich August Hackmann, Johann Christoph Adelung and later Jacob Grimm investigated the narrative genealogy and linguistic evidence of the Middle Low German versions and integrated the old branch of the tradition into a scholarly discourse on literary, linguistic and even juridical history. ${ }^{31}$ This endeavour involved keeping a critical eye on recent translations and contemporary accounts of the Reynard tradition and quoting extensively from older editions and editors down to the humanists, even where their philological assumptions were misleading.

The aesthetics of Goethe's Reineke Fuchs break with these generic and discursive conventions. On the one hand, by choosing the hexameter Goethe distances himself from the popular tradition, which expected either prose or Knittelvers. An anonymous reviewer of the Allgemeine Literatur-Zeitung had no sympathy for Goethe who refashioned the 'herrliches Denkmal altdeutscher Art und Kraft' in a complex non-Germanic meter:

Denn die gänzliche Geschiedenheit des Reineke Fuchs von aller Annäherung an griechische Form dünkt uns eben das, was dieses Gedicht so wahrhaft national für uns macht, und worin hauptsächlich jene ächt-volksmässige Darstellung beruht $[\ldots]^{32}$

In view of his earlier epic attempts such as Der ewige Jude, we may assume that Goethe was aware of the stylistic and cultural implications of his preference for a meter that was traditionally linked to religious epic. ${ }^{33}$

\footnotetext{
${ }^{29}$ E.g. Goethe's use of the word 'Hausfrau'. Well-known to the readership of Voss's Luise, the epithet is introduced in Reineke Fuchs to ironize cruelties or to fashion Malepartus as a bourgeois idyll (see VII, 2 I6; VI, 53).

${ }^{30}$ See Schmidt, "Pfingsten, das liebliche Fest", and Hubertus Menke, "Ars vitae aulicae oder descriptio mundi perversi? Grundzüge einer Rezeptions- und Wirkungsgeschichte des Erzählthemas vom Reineke Fuchs', Jahrbuch für niederdeutsche Sprachforschung, XCVIII/IX (I975), 94-I 36 (pp. I I2-25).

${ }^{31}$ See Friedrich August Hackmann, Programma de morali apologo poetico, qui nostra vernacula De Reineke Vosz appellatur, Helmstedt, I707, and Hackmann's edition of Reineke Vos: Mit dem Koker, Wolfenbüttel, I7I I; Johann Christoph Adelung, Fortsetzung und Ergaenzung zu Christian Gottlieb Joechers allgemeinem Gelehrten-Lexico, Leipzig, I784-87, I, 516-I7; Jacob Grimm, Reinhart Fuchs, Berlin, I834; Johann Carl Henrich Dreyer, Abhandlung von dem Nutzen des treflichen Gedichts Reinke de Voß in Erklärung der teutschen Rechts Alterthümer insonderheit des ehemaligen Gerichts-Wesens, Wismar, I768.

32 Allgemeine Literatur-Zeitung, No. 37I (3 I December I804).

${ }^{33}$ On the 'Koalition von biblischem Stoff und Hexameter' see Martin, Das deutsche Versepos, pp. 20, 438-40. On Goethe's choice of hexameters as a violation of convention, see Karl Wilhelm Böttiger, Literarische Zustände und Zeitgenossen, Leipzig, I 838 , I, 234.
} 
On the other hand, Goethe omitted to reflect on his use of the sources, his approach to the previous tradition or its cultural significance, as many of his contemporaries would have expected him to. 'Zum Beschlusse wünschten wir noch,' a reviewer remarks in the Tübingische gelehrten Anzeigen of 4 September I794, 'dass es Hrn. Goethe hätte gefallen mögen, in einem Anhange hier und da Anmerkungen zur Erläuterung gewisser Umstände, sprüchwörtlicher Redensarten und Sprachbeziehungen anzuhängen.' Goethe, who only one year later would confess that he saw an 'unübersteigliche Scheidewand' between his poetic production and 'dem heillosen Beginnen des Kritikers', fails to satisfy such expectations. ${ }^{34}$

As can be seen from these selected responses, Goethe's text proved troublesome not just for an immanent and intertextual reading, but also in relation to general discursive features of the literary field in the eighteenth century. They suggest that Reineke Fuchs should be read less as an example of a synthesizing 'middle way' between individual genius and national consciousness, ${ }^{35}$ but rather as a complex attempt to transgress conventions of reception in order to create, as Dieter Martin has shown for Goethe's later epics, 'einen originellen Beitrag abseits der Bahnen der Gattungsgeschichte' 36

Reineke Fuchs is a deeply ambiguous text and still something of a 'blind spot', 37 and it has troubling implications for the notion of original composition. Goethe's epic writing invites the reader to replace the value-loaded dichotomy 'originality/ traditionalism' with a reading that identifies and describes the processes from which originality evolves as an integral aspect of poetological conceptualization and a dominating concept of the discourse on poetry in general. Reineke Fuchs allows the reader to explore the genesis and the subversive conditions of such a process in detail. In contrast to a persistent prejudice, Goethe's Reineke Fuchs is not merely a versification of Gottsched's prose version, but a radical challenge to existing branches of the literary tradition. Goethe's variations, omissions and additions significantly extend and problematize the function of rhetoric and the ethical dimension of speech in Reineke Fuchs. Reineke Fuchs may thus be located at a threshold: 'Goethes Rhetorik steht nicht nur an einer Umbruchsituation der Rhetorikgeschichte, sie ist selber Ereignis des Umbruchs zur Moderne'. ${ }^{38}$ Goethe's poem was an affront to the popular view of Reineke Fuchs as central to the national culture, and to genre conventions of the German epic. Furthermore, Goethe's appropriation of the narrative tradition had a formative impact not only on the subsequent reception of Reineke Fuchs in German literature, but also on the modern perception of the earlier tradition in general. Goethe's Reineke Fuchs displaced a

\footnotetext{
${ }^{34}$ On F. A. Wolfs Prolegomena ad Homerum: Ernst and Renate Grumach (eds.), Goethe: Begegnungen und Gespräche, Berlin/New York, I965-, IV, I47-48.

${ }_{35}$ Nicholas Boyle, Goethe: The Poet and the Age, vol. I: The Poetry of Desire, Oxford, I992, p. 39.

${ }_{37}^{36}$ Martin, Das deutsche Versepos, p. 3 I 4.

${ }^{37}$ According to Friedrich Gundolf Reineke Fuchs is a product of the 'Interregnum' between Italy and Schiller (Goethe, Berlin, I9ı6, p. 484). See more recently Ernst Busch, 'Das Verhältnis der deutschen Klassik zum Epos', Germanisch-Romanische Monatsschrift, XxIX (I94I), 257-72, and Martin, Das deutsche Versepos, p. 444.

${ }^{38}$ Helmut Schanze, 'Goethes Rhetorik', in Rhetorik zwischen den Wissenschaften: Geschichte, System, Praxis als Probleme des 'Historischen Wörterbuchs der Rhetorik', ed. by Gert Ueding, Tübingen, I99I, pp. I39-47 (p. I40).
} 
tradition of almost three hundred years. As a result, today it might seem to the literary historian as if a prolific tradition from the humanists to Gottsched and the philologists of the subsequent generation was merely an organic prelude, not yet Goethe, but paving the way for him. On the other hand, with its ambiguous, dynamic construction of characters, its diversity of rhetorical styles and destabilizing tropes, Goethe's text proved an exceptionally fertile soil for further poetic reception. In the context of the Reynard the Fox tradition, Goethe's text might be understood in terms of Derrida's horticultural metaphor of 'grafting'. While Reineke Fuchs may be understood as the product of a 'force of rupture' with respect to previous poetic concepts and the Reynard tradition in particular, the process of 'inscribing or grafting it into other chains' of reception has given Goethe's model the status of a new archetype for modern narrative scions. ${ }^{39}$ Paradoxically, Reineke Fuchs may thus be read both as a subversion and as a revitalization of a narrative tradition to which Goethe attached his name.

This opens up fundamental questions about the perception of Goethe's work and its function in the discourse of German studies. The 'animal troubles' of Reineke Fuchs indicate an immanent challenge to the established view on Goethe's writings as 'Bruchstücke einer großen Konfession' (FA, i, XIV, 3Io). They draw attention to rupture as a pre-condition of this 'Konfession' and of the teleological construction of Goethe as the national poet. In this respect, T. S. Eliot's reading of Goethe still offers a fruitful provocation for the modern critic:

The more I have learnt about Goethe [...] the less I find it possible to identify him with his age. I find him sometimes in complete opposition to his age, so complete perhaps as to have been greatly misunderstood. ${ }^{40}$

The provocations of Goethe's poem offer an insight into the poetic controversies of an age that was marked by greater tension and complexity than literary historiographers are generally willing to acknowledge.

\footnotetext{
${ }^{39}$ Jacques Derrida, 'Signature Event Context', in Derrida, Margins of Philosophy, trans. by Alan Bass, Brighton, I982, pp. 307-30 (p. 3I 7 ).

${ }^{40}$ T. S. Eliot, 'Goethe as the Sage', in Eliot, On Poetry and Poets, London, I957, pp. 207-27 (p. 218).
} 